\title{
Music for the Pria Dewasa: Changes and Continuities in Class and Pop Music Genres
}

\author{
Emma Baulch \\ Australian National University
}

\begin{abstract}
This paper presents Rolling Stone Indonesia ${ }^{1}(R S I)$ and places it in an historical context to tease out some changes and continuities in Indonesian middle-class politics since the beginning of the New Order. Some political scientists have claimed that class interests were at the core of the transition from Guided Democracy to the New Order, and popular music scholars generally assert that class underlies pop genre distinctions. But few have paid attention to how class and genre were written into Indonesian pop in the New Order period; Indonesian pop has a fascinating political history that has so far been overlooked. Placing RSI in historical perspective can reveal much about the print media's classing of pop under New Order era political constraints, and about the ways these modes of classing may or may not have endured in the post-authoritarian, globalised and liberalised media environment. ${ }^{2}$
\end{abstract}

1 The article introduces the Indonesian-licensed edition of Rolling Stone magazine. The title of the Indonesian edition is, like that of the principal publication, simply Rolling Stone. However, for clarity's sake, this paper refers to Rolling Stone Indonesia, abbreviated to RSI.

2 This paper is part of a three-year research project titled "Middle Classes, New Media and Indie Networks in Post Authoritarian Indonesia", begun in March 2009, funded by the Australian Research Council. Thanks to Gde Putra for his invaluable assistance and insights; to Ariel Heryanto for his supportive leadership; to the School of Culture, History and Language at the College of Asia and the Pacific, Australian National University for administering the project' and to the Australian Research Council for funding it. Thank you to Marshall Clark, Brett Hough, Jeroen de Kloet, Jeroen Groenewegen, Barbara Hatley, Aline Scott Maxwell, Julian Millie and Hyunjoon Shin, for their thoughtful and helpful comments, as well as to audiences at the International Seminar on Media, Culture and Society at Airlangga University in Surabaya; International Cultural Studies Symposium at Udayana University in Bali; International Convention of Asian Studies in Daejeon, the Indonesia Council Open Conference at the University of Sydney; and Monash University's Centre of Southeast Asian Studies seminar series, where parts of this paper have been 


\section{Introduction}

Driving down the haphazard, traffic-choked Jalan Raya Cilandak in South Jakarta - that area of the city understood to harbour the well-todo and the media savvy - one comes across an impressive structure that stands out from the office buildings that sprouted in the capital during the New Order period. Nestled comfortably in a generous, exquisitely manicured block, this two-story building recalls the Pompidou Centre in Paris, but for the large, glittered red letters that garishly announce it as Rolling Stone's Indonesian headquarters. It features a surfeit of white piping and perspex panels. There is so much perspex that passers by can watch the mundane comings and goings inside; it is like watching somebody's digestive system.

Seeing inside is easy, but getting inside requires quite an effort. Although there is no fence and it is open to the street, this office building is guarded strictly. Even after many visits to interview writers for this piece, I had to report first to one of the security guards outside, name the person I had an appointment with, then wait for that person to come out, collect me, and escort me through the front door.

The building overstates the magazine's commercial clout. Its circulation is a mere 10,000 and, after five years of operation (the first issue was in May 2005), the magazine is yet to break even. In 2004, a team of people including the owner, Eddie Soebari, who sits on the Board of Directors of the Indonesian mining giant, PT Bumi Resources; Monika Soebari, the current President Director of RSI (and Eddie's wife); and Andy F Noya, the former editor-in-chief of the news channel Metro $\mathrm{TV}$, puttogether a business plan to present to the editor of the New York Rolling Stone, Jann Wenner, as a proposal to gain an Indonesian licence for the title.

Soebari's bid was not the first from Indonesia, but it was the first to succeed, and thereby became the first Indonesian-licensed publication devoted to rock and roll. At the time of writing, it remains the only such publication — other Indonesian music magazines are local titles.

presented. Any shortcomings, errors of fact or of interpretation remain all mine. 
In 2009, RSI's four-year title was renewed, and the licence agreement renegotiated. As they intimated in my interviews with them, many $R S I$ staff writers breathed a sigh of relief at the news of the renewal, they are well aware of the vagaries of the Indonesian music press (Solhun, 2004), as well as the intense competition among the print media for advertisers because they generally devote the bulk of their advertising budgets to television, which has a much bigger audience.

For precisely this reason, $R S I$ is no profitable venture. However, the owners claim, they did not expect it to be. Consistently, less than twenty per cent of its 120 pages have advertisements. In the original business plan that was presented to Jann Wenner in 2004, Soebari proposed subsidising the magazine with income from leasing or staging sponsored events at the Rolling Stone live venue, which is in the opulent backyard of the magazine's office building. Because it presents the possibility of television coverage, a live venue is likely to attract more advertising than does a magazine.

At the time of writing though, the live venue had only just begun to operate, and the four years from 2005 to 2009 was a time for the magazine to develop its local brandidentity. The business plan for RSI was devised with a specific market in mind. At the time of the license bid, senior editor Adib Hidayat related, a number of publications written for pria dewasa (adult male) were on the Indonesian market. These include magazines dedicated to national news (Tempo), health (Men's Health), fashion (Esquire) and women's bodies (FHM). But before the publication of RSI, there was no such magazine dedicated to music in Indonesia.

Pria dewasa directly translates as 'adult male', but a particular socioeconomic positioning is implied in that notion of adulthood. Ricky Siahaan characterised RSI's readers as belonging to segments 'A and $\mathrm{B}+$ ', referring to the categorisation system employed by the media research company, Nielsen Audience Measurement (Indonesia), to estimate the confluence of media consumptions with socio-economic positioning. Adib Hidayat characterised the readers that Tempo, Men's 
Health, Esquire and FHM conjure as 'young established executives', a characterisation that immediately brought to my mind exemplary New Order subjects, the very proof of Pembangunan's success.

RSI's evolution since its inception, then, is ripe for an exploration of the ways in which ideologies of class, of pop and of print media come together in the magazine's attempts to herald the pria dewasa; it offers a chance to consider changes and continuities in these ideologies since the advent of the New Order.

In what follows, I argue that RSI's attempts to herald the pria dewasa retrieve representations of 'the people' to emerge in print journalists' critiques of pop music at the dawn of the New Order and through to the early 1980s. That these representations of the people in music criticism urged a reading public to imagine itself as a 'middle' is a point already noted by some other scholars (Weintraub, 2006). ${ }^{3}$ However, below I argue that denigrations of the popular in print at this time might be understood as something more contextual and more political than a natural product of a middle-class elitism that manifests universally, as Weintraub and others (Browne, 2000; Murray, 1991) imply. ${ }^{4}$ Indonesian middle-class activism has a long history and many different flavours. Images of the people to emerge in RSI might aptly be thought of as continuous with a particular chapter of this history, in which a new kind of print capitalism, a particular vanguardist middle sensibility, and the establishment of an unequivocally pro-USA, military-dominated

3 In this paper, to stress its mythical dimensions, I try to avoid use of the term 'middle class', prefering instead 'middle sensibility' or 'senses of middleness'. The middle sensibility that emerged in the New Order period as discussed in this essay is more than simply elitist. It betrays activism, and bears resemblance to Pandey's characterisation of the specifics of post-colonial middle classness. He (2009: 328) writes: 'As they announced their struggle and their arrival, the middle classes in the colony spoke not only for themselves or for some abstract universal - the work ethic, merit, temperance, progress - but also for their people, who had been marked as "backward" and whom the educated middle classes had to represent and lead into the modern.'

4 Browne and Murray both contend that Melayu-kampungan contains values that are inherently other to those of the middle class. Browne (2000: 10) contends that 'middle class values' co-opt dangdut and, according to Murray (1991: 10), dangdut provides an alternative to 'bourgeois norms'. However, neither Browne, Murray nor Weintraub elaborate on how they conceptualise class, nor engage at all with existing literature on class in Indonesia, and such omissions have the effect of naturalising and universalising 'middle class'. 
regime that followed the annihilation of the left, all intersected. Further, this annihilation was particularly violent and it should not be underestimated that representations of the people in print and elsewhere were considerably constrained.

It is also important to note that $R S I$ occupies an historical moment with complexities and should not be considered a typical snapshot of contemporary middle-class cultural politics. Hence, I advance this argument for $R S I$ as evidence of the continuity of intersecting ideologies of class, pop and print that grew in the New Order period but with two important caveats. First, although vanguardist representations of the people who appear to aid the magazine's heralding of the pria dewasa are striking, they do appear beside more meekly expressed irony, suggesting that the magazine also serves as a liberal realm of experimentation and reflection. There is not space in this article to explore such irony, which complicates RSI's address.

Second, vanguardist representations of the people in RSI seem increasingly beleaguered in the face of enormous upheavals on a number of fronts, which splinter a middle sensibility that was previously more coherent. The concurrent transformation of political and media spheres over the past two decades is far too widespread to be detailed in a single article, so in the final section of this paper, I argue that it is possible to gain a sense of such splintering by focussing on one of its facets: the changing meanings of pop music genres. Such changes include more populist representations of the people, and mean that the old ways of evincing a vanguardist middle are much more contested.

As an exploration of what RSI reveals of the links between class, pop music and print media, this paper is indebted to a growing scholarship on Indonesian music journalism (Mulyadi, 2009; Solihun, 2004; Sopiann, 2002; Weintraub, 2006), as well as the literature that considers the evolving relations between Indonesian print journalism, moral authority, political legitimacy and dissent (Dhakidae, 2003; Farid, 2005; Heryanto, 2003; Heryanto and Adi, 2002; Hill, 1994; Keane, 2008; Romano, 2003; Steele, 2005). In the first section of the article, and building on Mulyadi (2009) and Weintraub (2006), I seek to stress 
the political significance of Indonesian pop genres by placing their evolution in the context of a budding middle sensibility in concert with a new chapter in print capitalism on the advent of the New Order. It is upon this political history that my assessment of the extent of postauthoritarian rupture is based.

The paper is also indebted to, and seeks to extend, scholarship on Indonesian pop. To clarify some terms that will be used throughout this paper, it is worth briefly noting some features of this scholarship: how Indonesian pop music relates to class has been a compelling question for a lot of writers. ${ }^{5}$ In fact, how the genres 'Indonesia' and'Melayu' are connected to people's position in some kind of a class-like system has been a central theme in scholarship on Indonesian pop. ${ }^{6} \mathrm{~A}$ kampungangedongan dichotomy is quite often invoked as a description of how a class-like system manifests itself in an Indonesian context. Kampungan-gedongan literally refers to the built environment (of the slums-of the buildings) but signifies more widely positions of centrality and marginality in relation to the metropolis, implying vulgarity and refinement. ${ }^{7}$ The question many writers have pursued is how and why the pop genre,Melayu, has become linked to kampungan but gedongan has become associated with pop Indonesia.

Yet to be analysed in this scholarship is the fact that a coherent middleness now seems increasingly beleaguered; enormous upheavals on a number of fronts splinter Melayu-kampungan and Indonesiagedongan alike. The second section of the article sets RSI's retrievals

5 See Barendregt, 2002; Baulch, 2007; Browne, 2000; David, 2003; Frederick, 1982; Gjelstad, 2003; Heins, 1975; Heryanto, 2008; Luvaas, 2009a; Murray, 1991; Pioquinto, 1995; Piper and Jabo, 1987; Wallach, 2002 and 2008; Weintraub, 2006; Yampolsky, 1989.

6 Pop (and rock) Indonesia refers to songs usually sung in the national tongue but making use of Western pop idiom. Melayu ranges from dangdut, a hybrid form distinguished by consistent use of a Melayu vocal style, bamboo flute (suling) and twin goat-skinned drums (gendang), to pop Melayu, distinguished through use of iconic elements of the Melayu vocal style, but otherwise using Western instrumentation (of which more below). Melayu is generally understood as a genre somehow derivative of Indian film music but contains varying degrees of proximity to a Bollywood sound.

7 A precise translation of kampungan is elusive. Kampung evokes the masses' ephemeral urban dwellings and their rural homelands. Such imprecision has the effect of relegating all but a gedongan centre to marginal status. 
of Melayu-kampungan, its redrawing of pop Indonesia-pop Melayu distinctions, in the context of such splintering.

\section{Middleness, Pop Genre and Print}

Throughout Indonesia's post-colonial history, genre conventions that have endured are those separating music perceived as being derived from those originating in the West (such as pop Indonesia) from that perceived as being derived from and paying homage to Easternness (such as Melayu). But what changes radically in the transition from Guided Democracy (1959-65) to the New Order (1966-98) is the political context that affords these genres social significance. A little over forty years ago, pop Indonesia, and its assumed proximity to a gedongan reality, came to assume positive connotations. This development cannot be divorced from attempts to paint the New Order as a new beginning.

The transformation of pop Indonesia from transgressive to sanctioned can only be understood in the light of the prohibitions placed on the airing of 'Western' pop music in the national public space during the Guided Democracy period. In separate writings, Mohamad Mulyadi and Agus Sopiann detail the military's use of state-prohibited Western-style pop and rock music to involve people in its new regime of governance (Mulyadi, 2009: 20; Sopiann, 2002: np). Mulyadi (2009: 3) recounts how the military sponsored an intense program of daily musical events on the radio that showcased pop musicians performing all the officially forbidden genres. These broadcasts, known as "soldier stages" were co-ordinated by an outfit called Body for Co-operation between Artists and the Army Strategic Command. According to Mulyadi, 'the Body's strategy to invite those artists who had been banned by Soekarno was part of an effort towards moral transformation' (Mulyadi, 2009: 3, 20)

Popularisation of the idea of the novelty of military rule, then, through performances of 'forbidden' music, was one of the first tasks of the leaders - a task that well preceded the flow of foreign capital for infrastructural development. At the same time, the desire for this kind of novelty often appeared as popular will, for it was sometimes 
quite enthusiastically taken up by non-state elements. 'New Order, New Atmosphere, Everything is Completely New' proclaimed an advertisement for a transistor radio that appeared in the magazine of the national public radio in December, 1967 (Mulyadi, 2009: 20).

What troubles the link between aesthetic Westernisation and newness is the development of a new Melayu sound in the early 1970s. This sound, which subsequently became known as dangdut, became enormously popular throughout the 1970s, 80s, and 90s. Scholarship on dangdut is fabulously varied in its interpretations of the genre and this may be because of the diverse range of contexts in which dangdut is played and heard, and its endurance beyond the New Order, which has forced new political interpretations (Browne, 2000; David 2003; Frederick, 1982; Heryanto, 2008; Murray, 1991; Pioquinto 1995; Wallach, 2008; Weintraub, 2006). There seems little doubt that those who are now recognised as responsible for creating what has become known as dangdut set out to develop a new kind of Melayu sound (Frederick, 1982). Once carved out as a genre, dangdut may well have opened space for performing despair or rough communality in ways that flaunted transgression of prevailing notions of the refined, perceived as proximate to the modern. However, we should be careful not to focus our inquiries only on dangdut's appeal, thereby assuming the existence of 'the people' as dangdut's source.

With such an enormous variety of interpretations and of performance and consumption contexts, let me begin by specifying what I want to say about dangdut. First, dangdut was hatched, employed then re-employed in those print media that sought to evoke a sense of a reading public as a middle position, ambivalently positioned vis-à-vis the state, but unequivocally Other to the unknowing masses, and depicted as victims of looming forces such as Development and Mass Media. Second, that dangdut was able to serve as a sign of the unknowing masses says much about the political environment of the day.

'[T]he name "dangdut" is actually an insulting term used by "the haves" toward the music of the poor neighborhoods [where it originated]', explains Rhoma Irama in Weintraub's analytical piece on dangdut's 
representation in the print media. 'They ridiculed the sound of the drum, the dominant element in Orkes Melayu [one of dangdut's musical precursors]. Then we threw the insult right back via a song, which we named "Dangdut" (Weintraub, 2006: 414). According to Weintraub, the offending term originated in an article printed in the celebrated news magazine, Tempo. Certainly, Irama's statements illustrates that the term was very quickly excorporated, and this complicates the Melayu-Indonesia relation somewhat, a point Weintraub does not stress enough. The main point to be made here concerns the core argument of Weintraub's piece, and a point also touched upon (but less forcefully) by several other observers of Indonesian pop. As Browne (2000), Mulyadi (2009), Solihun (2004) and Weintraub (2006) all attest, rehabilitations of Melayu-kampungan have very often taken place in print media. Incidentally, all these writers cite those publications that have been key to the heralding of an Indonesian middle in the New Order period. Weintraub (2006: 413) considers most directly the matter of Melayu-kampungan as part of addressing the middle class, and devotes his article to the question of 'what kind of story has been told through dangdut about the people in popular print media?'. ${ }^{8}$ He states (2006: 417):

Dangdut became a social text for assigning all sorts of meaningskampungan for example - through which elites could register their own class position... Dangdut fans, synonymous with the masses, were discursively produced in popular print media according to middle class and elite notions of the rakyat [the people] as explosive and uncontrolled.

Pop music criticism was not a particularly promising career choice in New Order Indonesia, but representations of the people in print media articles about music are relevant, and can be located in a broader context of a mythology of middleness that grew in key publications, part of a new chapter in print capitalism on the advent of the New Order. In proposing a mythology of middleness, this article goes against the

8 Weintraub's use of the word 'popular' is confusing, because he cites Tempo extensively. 
grain of much scholarship on the middle class in the New Order period, which posits that quantifiable growth took place as a result of New Order economic policies (Crouch, 1986; Dick, 1990; Jaya, 1999; Hadiz and Dhakidae, 2005: 21-2; Lev, 1990: 29; Tanter and Young, 1990: 7; Robison, 1986; Zulkarnain et al., 1993). This article also resists the idea that an Indonesian middle-class identity can be singularly associated with the political vision of those groups of intellectuals who supported the establishment of the regime, then became disillusioned with it.

These prevailing impressions of a New Order-period middle-class growth, and of an Indonesian middle-class political vision comparable with that of the New Order regime's early supporters, gain particular relevance for the current paper in their marking of some scholarly discussions of the Indonesian press and, obliquely, of scholarship on pop music. ${ }^{9}$ For example, suggesting they may also be a product of New Order economic policies that gave rise to growth, Keane characterises Tempo's readers as 'primarily members of Indonesia's tiny urban elite and middle classes...reflected in the steep cover price and the predominance of advertisements featuring luxury goods' (Keane, 2009: 51; emphasis added). In her book on Tempo magazine, Steele draws on Robison (1996) to stress the links between New Order-period middle classness and anti-communist intellectual activity in the early and mid1960s. In this way, she masterfully highlights the magazine's political roots, but risks essentialising and universalising class by glossing over the various Indonesian middle sensibilities, populist and non-populist alike, which have emerged under various political conditions. ${ }^{10}$

9 With few exceptions, scholars of Indonesian pop have failed to elaborate on how they conceptualise class, nor engage at all with existing literature on class in Indonesia, and such omissions have the effect of naturalising and universalising 'middle class'. To cite two examples, Browne and Murray both contend that Melayu/kampungan contains values that are inherently other to those of the middle class. Browne (2000: 10) contends that 'middle class values' co-opt dangdut, and according to Murray (1991: 10), dangdut provides an alternative to 'bourgeois norms'.

10 For example, we might contrast turba (turun ke bawah, literally, going down into) - the cultural organisation Lekra's program of artist-intellectuals living side by side the masses in order to attain enlightenment - with the kinds of New Order period representations of the people that kampungan-gedongan distinctions evince. Both conjure an activist middleness, but turba motions to the idea of the suffering masses as a vanguard in the struggle to realise a particular modernity, but New Order period pop genre distinctions, as discussed 
Rather than as a reflection of existing social entities or naturally occurring middle-class a-populism, pop genre distinctions and their attendant kampungan-gedongan dimensions are more usefully considered in a context in which print media have played a crucial role in building, and continuously reinforcing, a myth of class. As a number of observers have documented, several publications that developed later into conglomerates began to flourish during the New Order regime, which limited licenses and therefore competition (Hill and Sen, 2005: 18-19). Also notable is the image, gleaned from scholarship on the New Order-period press, of print journalists as ambivalent scribes whose writings often contributed to a particular sense of Indonesian middleness by appearing to support the rulers, but upheld a myth of the press as a rights defender (Dhakidae, 2003: 366; Heryanto and Adi, 2002: Hill, 1994; Keane, 2009: 48; Steele, 2005: 169; Lev, 1990: 29). The news magazine, Tempo, established in 1971, has been the subject of particularly intensive analyses (Dhakidae, 2003: 379-382; Hill, 1994: 88-91; Heryanto, 2003; Steele, 2005).

Steele's book on the magazine offers an especially vivid depiction of this ambivalent positioning. In her chapter discussing depictions of the nation in Tempo, she points out that 'the contents of Tempo's National section followed what is widely understood to be the pro-development agenda of the New Order' (Steele, 2005: 152). But she holds to her interpretation of dominant depictions in Tempo of the masses as victims of economic development as evidence of the magazine's mission as a rights defender and cites Liddle, who characterises that mission as 'to defend those who cannot defend themselves' (Steele, 2005: 157).

As Heryanto (2003; see also Pandey, 2009 for a more general discussion) points out, myths of the press and of class are interlocking. Intellectuals in many post-colonial countries often serve as torchbearers for middleclass activism, and enjoy an influence that exceeds what their numbers would suggest; influence that is partly realised in and through the press.

by Weintraub, suggest a-populism. Weintraub, however, does not discuss the broader, apopulist political environment in which these representations appear, hence also intimates a naturally-occurring middle class a-populism. 
It is therefore not surprising that the mythical dimensions of the press and class by no means preclude their implications for political action protesting against the rulers. For example, Dhakidae highlights how New Order-period middleness was ambivalently positioned vis-à$v i s$ the rulers but nevertheless stayed proximate to a myth of the press as rights defender. He (2003: 371) notes how, despite its legacy as a magazine that documented the New Order successes, Tempo inspired unprecedented public protests when it was banned in 1994. Keane suggests that the protests reveal how Tempo incorporated a global ideology of the press as the embodiment of freedom and voice, part of the valorisation of a secular modernity. But Heryanto and Adi (2002) point out that an Indonesian myth of the press rests not just on its role in the struggle for independence. In a context where formal literacy levels remain low, it also contains sacred dimensions, and feeds into a myth of middle-class, intellectual activism. In the New Order period, the genesis of the press, in concert with that of nationalism, was often invoked to valorise particular kinds of middle-class, intellectual activism, albeit under changed conditions and for different ends.

The ideological transformation that took place in the transition from Guided Democracy to the New Order is well known, but few have offered as detailed a perspective as Farid's (2005) on how such transformation was achieved. In an article in which he argues that there is a crucial link between state ('bureaucratic, vertical') violence (Farid, 2005: 4) perpetrated in 1965-6 and a new chapter in Indonesian capitalism, he discusses the new conceptions of class that emerged during this period. Specifically, he argues that the killings prompted the extensive alienation of people from their means of subsistence, further reinforced by the scrapping of land reform and the introduction of the Green Revolution. This process, Farid asserts, may be described as one of 'primitive accumulation', whereby the idea of a labour force became justified. Previously, Indonesian capitalism was severely compromised by widespread non-capitalist and anti-capitalist social practices (Farid, 2005: 13). 
Although others have gestured to ideas that resemble his thesis (for instance, Tanter and Young 1990: 7), Farid is the first to launch a thorough critique of the enduring idea that the New Order provided the conditions conducive to a quantifiable middle-class growth, and that quantifying such growth is a scholarly activity of utmost importance. More important, in Farid's view, is the link between state violence and a new chapter in Indonesian capitalism. It is basic that the annihilation of language and ideas associated with anti-imperialism and democracy was achieved partly through the speedy establishment of new systems for state control of the press, which entailed extensive sackings and bannings (Farid, 2005: 6). Notably, the state's wishful and forceful vision of the people's depoliticisation - a hope expressed in the term 'floating masses'-impresses the political constraints imposed on the evolution of a middle sensibility during this time.

Farid's discussion of the transformation of the material conditions and of prevailing perceptions of the masses on the advent of the New Order is of great relevance to this paper. The use of pop Indonesia-gedongan to herald the New Order's newness has already been discussed and, with Farid, we might characterise this too as a facet of primitive accumulation. Such performances were highly suggestive of the ideological transformation, including the transformation of prevailing state-sanctioned images of the people, which was to take place. As mentioned, images of the people as disempowered and unknowing emerge repeatedly in press articles about popular music, and may be seen to aid the sense of middleness that grew with a new chapter in Indonesian print capitalism. As also mentioned, this middle was conjured in ambivalent relation to the rulers, but as an unequivocal Otherness to the unknowing or floating masses. It is this aspect of middleness, as a relation of unequivocal Otherness to the floating masses, that Melayukampungan evinces.

Inthecurrentdiscussion, the intersecting myths of the press, ofmiddleness, and of pop genres, are of vital importance to an understanding of the contemporary developments in class as revealed in an analysis of RSI. However real their influence on events, such myths elude quantifiables, 
such as notions of the growth of particular societal sectors or the kinds of consumer products members of some classes favour. Below, I shall argue that $R S I$ is revealing of attempts to rehabilitate and continue the role pop music genres have played in a mythology of class that evolved with the advent of the New Order. Such efforts at continuity are evident in key content that marks the magazine as a class position. But let us first turn to some of the changes that have taken place in pop genres since the fall of the New Order in 1998.

\section{Local Music Boom}

In the years between the establishment of the New Order regime (1966) and that of RSI (2005), pop (including rock) Indonesia, a genre to which $R S I$ is devoted, has undergone considerable transformation. Above, I have argued that an Indonesia-Melayu distinction can be inferred from attempts to evoke a sense of a print media-reading public as a middle position. I have also drawn attention to how such distinctions involved particular representations of the people that are usefully understood in a political context. But recently there have been changes, including those in media ownership, media content and in the intensity of peoples' engagement with particular media technologies. Such changes were first sparked by media deregulation policies in the late-1980s but increased in momentum after Suharto's fall in 1998. As a consequence, ways in which the genres, Indonesia and Melayu, relate to the categories, 'the people' and 'the middle', has become indeterminate. The line distinguishing Indonesia from Melayu has also blurred.

The widespread changes that gave rise to this blurring are too various to be documented here. ${ }^{11}$ Suffice to say, although appearing to resist them, $R S I$ is very much part of many of these changes, which include the proliferation of Bahasa Indonesia versions of foreign magazine titles under license agreements and the striking rise in the production and consumption of pop Indonesia, making a glossy magazine devoted to

11 On media deregulation see Sen and Hill (2000) and Baulch (2007a). On the globalisation of the recording industry, see Baulch (2007b). On developments in the intensity of Indonesians engagements with new technologies, see Heryanto (2010) and Hill and Sen (2005). 
pop Indonesia a viable business venture. Further, the recording industry has structurally globalised since the deregulation of some sections of the Indonesian media, beginning in 1988. Over the past fifteen years, several multinational recording companies have established branches in Jakarta.

Paradoxically, over the same period, and in contrast to the foreignness that has traditionally been assigned to the genre, pop Indonesia has gradually assumed the mantle of 'local music'. Not only have sales of pop Indonesia overtaken by far those of Anglophone pop, the meaning of pop Indonesia itself has also changed in more qualitative ways, which a sole focus on sales statistics will leave unnoticed. For example, attention to the ways in which Indonesian fifteen to twenty-year-olds now encounter music suggests an entirely different experience from that of fifteen years ago, when any discussion of pop Indonesia inevitably involved currently popular American or English acts. This is no longer the case, as highlighted by a recent conversation with an amateur Balinese musician, seventeen-year-old Komang.

Komang is a talented guitarist and vocalist and has been in a number of amateur pop bands. She is an avid fan of the pop Indonesia acts Cokelat and Afgan, but her broad active listening crosses genre lines: she claims a deep appreciation of the dangdut vocal style and of the (pop Melayu) Kangen Band's tunes. This is not someone with limited musical interests and horizons. One day, as I chatted to her, a song by the band Dewa filled the air. It reminded me of a Beatles song and I asked her if she had made the same association. Given her deep musical involvement, I was taken aback by her reply: 'Who are the Beatles?'.

Ten years previously I conducted some research among Balinese men around the same age as Komang, also amateur musicians. I had found that among them, questions similar to the one I had posed to Komangcomparing pop Indonesia sounds with those from Anglo-Americawere prominent in their imaginings of the field of pop music production. Questions about pop Indonesia composers' Anglo-American influences were highly important to those amateur musicians' consumptions of $p o p$ Indonesia. Perhaps we may interpret this compulsion as a reinforcement 
of pop Indonesia's status as derivative, and as evidence of yet another of the burdens modernity imposes upon post-colonial people; the burden of responding to the idea that modernity originates in Euro-America and can only be imperfectly copied by the rest of the world. The young men among whom I conducted research in the late-1990s seemed to assume this proposition as truth. (Paradoxically, they strategically employed this assumption to empower themselves, but that is another matter.)

But in Komang's reply, we see a different way of imagining the field of pop production. Her ignorance of the Beatles illustrates a profound change in the way Indonesian consumers of pop Indonesia perceive the world of cultural production. Although some pop Indonesia musicians continue to cite Anglo-American acts as sources of inspiration, in the minds of many pop Indonesia consumers, the genre has nothing to do with the West. It is produced in Jakarta, for a national audience, and most often sung in Bahasa Indonesia.

It may not be surprising that $R S I$ celebrates this boom in production and consumption of pop Indonesia - it provides, after all, one material reason for RSI's existence. That said, $R S I$ is no mere reflection of the material conditions that make its existence plausible. In fact, the very ubiquity of pop Indonesia renders the task with which RSI's writers have been charged - that of heralding the pria dewasa - rather tricky. In the face of the genre's omnipresence, the value of pop Indonesia becomes quite uncertain. Since the turn of the century, for recording companies, composers, producers and performers, pop Indonesia has come to represent promising commercial opportunity. But it is also more available than ever before to the masses; the gedongan mould is no longer a comfortable fit for pop Indonesia. What kinds of writing, then, might enable this increasingly mundane, dispersed cultural text to address an extraordinary group of people, the pria dewasa?

Below, I suggest RSI does so in two ways. First, it infers a male (pria) reader by conflating the kampungan with feminine consumption, thereby adding overtones of femininity to the kampungan in new ways. Below, I shall briefly discuss how critiques of feminine consumption in 
$R S I$ may be read as a reaction to a generalised feminisation of the public sphere that has accompanied the rise of consumerism in Indonesia. Second, it addresses a dewasa reader by recovering Melayu-Indonesia distinctions.

\section{'Leave All That for Your Maid's Entertainment'}

In their separate studies of dangdut kampungan, Browne and Pioquinto discuss kampungan as a case of being gender assigned (Browne, 2000: 1; Pioquinto, 1995: 60). As these two writers state, dangdut kampungan is so partly because it involves female performers asserting their sexuality on stage - performances largely viewed by men. It is no surprise that RSI's sense of its own authenticity also derives partly from conflations of vulgarity and femininity. After all, as we have mentioned, the magazine is devoted to pria dewasa. But RSI, images of the vulgar feminine indicate some differences with the kampungan feminine that Pioquinto and Browne describe. In their writings, kampungan refers to female performers, but in RSI, kampungan is evoked through representations of feminine consumption.

This kind of fusion appears in Wendi Putranto's feature on Glenn Fredly, a composer and singer who is known for the syrupy ballads he composes and sings. Before the appearance of Putranto's feature, Fredly had been the subject of the many television shows that are dedicated to the love lives of Indonesian celebrities because he was divorcing his wife, Dewi Sandra, also a singer. Putranto uses the news of Fredly's divorce as a hook to contrast with his own article, which is about the singer's political concerns. In so doing, he assumes his readers are people who employ female domestic workers but belong to a completely different cultural realm from their employees. He allows the readers to relegate Fredly's marital woes to the cultural realm of female domestic workers, a realm of television and of frivolous consumption, and urges them to focus on more serious issues: that of Glenn's concern for the environment, corruption and the state of the music industry (Putranto, 2008a: 101). 
Glenn confesses that he's been feeling restless lately. Trust me, this has absolutely nothing to do with his domestic affairs with his wife, Dewi Sandra. Leave all that for your maid's entertainment. Glenn is restless because of global warming, because of a country full of corruption, and because of the disastrous state of the music industry.

In the beginning of this article, I offered a translation of kampungangedongan that suggests it depicts class as a relation to the metropolis. But in this above-cited appeal, Putranto paints a slightly different picture. Here, he stresses gender, intimating kampungan's close associations with the frivolous, and with feminine consumptions, but gedongan describes the world of serious male pursuits, which betray activism, a concern for social justice and truth.

Putranto's gendering betrays a new context in which consumerist ideologies are fast being knitted into prevailing notions of Indonesian modernity, giving rise to the increasing presence of the feminine consumer in the national public space. As well as in the proliferation of soap operas, such feminisation is also manifested in the rapidly increasing number of shopping malls (which harbour countless experimentations with the feminine) and in the expansion of the Muslim fashion industry. Feminisation may also be seen in the increasing visibility of the feminine pop consumer, a trope that emerges with intensity in images of Indonesian pop since the aforementioned boom in the production and consumption of so-called local music.

By identifying those who employ female domestic workers with a concern for truth and justice, Putranto's statement calls forth a middle reader who resists such feminisation, and draws $R S I$ into a legacy of intellectual activism, hence continuing mythologies of class and print media already established. He returns to what Heryanto refers to as a 'familiar division' that plagues understandings of modernity; a division 'between the masculine world of news, scholarship and conferences versus the feminine world of soap opera, gossip, magazines and family matters'. Such gendering, Heryanto notes, is reiterated in Indonesia in the 'quality' media's chronicling of the proliferation of soap opera on television, as well as interpretations of their enthusiastic consumption 
(Heryanto, 2010: 193; see also Baulch, 2007b). ${ }^{12}$ Putranto's characterisation of Glenn Fredly ought to be seen to fall in with this pattern of chronicling, which has a deeper history, as I have argued.

One other important facet of RSI's classing, through its chronicling of developments in popular music, is the magazine's treatment of an old genre with new connotations: pop Melayu. Over the last two or three years, all the major, Jakarta-based recording companies have developed pop Melayu repertoires. The genre is known for its lyrical explorations of sexual infidelities and love relationships, and for its use of the cengkok vocal style reminiscent of the dangdut style. In contrast to dangdut though, pop Melayu compositions generally make use of Western instrumentation, not a bamboo suling (flute) or a gendang (paired hand drums). Pop Melayu's nods to dangdut can be very slight and barely noticeable. In recent years, in terms of sales, pop Melayu has emerged as an enormously successful genre.

The matter of pop Melayu's quality or lack thereof is quite a hotly debated issue. Despite these debates, the idea that pop Melayu bands are universally lacking in musical quality is something of a house position among staff writers at RSI. For example, in March 2009, as part of its regular profiles on the music industry, $R S I$ ran an article titled, 'This is Indonesian Music Today', which Wendi Putranto (2009: 65) introduced thus:

Pop Melayu bands have suddenly attacked the capital and have suddenly become superstars, with their uniform music. The people are given no choice in the matter because the mass media fully supports Melayunization. [The indie band] Efek Rumah Kaca is one of the only bands to rise up in protest, with their [ironically titled] song 'Nothing but Love', which became a minor hit.

12 Heryanto cites articles in the daily newspapers, Kompas and Jakarta Post, as well as surveys of media consumption by the media research firm Nielson Audience Measurement (Heryanto, 2010: 193). 
But most people don't seem to care and can't be bothered debating the issue. Most of the people enjoy buying pirate CDs or pirate MP3s, or picking out their 30 -second ring back tone, enjoy celebrating or rioting at free concerts. Many of them feel that cheating on their lover qualifies them to write a song. Recently, these phenomena have begun to clearly manifest in our society.

Unlike Putranto's characterisation of Glenn Fredly, this critique of pop Melayu accords not gender, but the metropolis, a determining role in assessments of degrees of vulgarity and refinement. Such concerns are not just expressed in Putranto's article. In striking contrast to the variety of opinions concerning the validity of pop Melayu's emergence on national stages, RSI's writers unequivocally scorned pop Melayu. Although high profile criticism of pop Melayu has not been limited to $R S I$ writers, their positions seem especially paradoxical; for selfprofessed investigative music writers, they showed a baffling lack of curiosity about this genre. ${ }^{13}$ Echoing Wendi Putranto's introduction, RSI writers, Ricky Siahaan and Hasief Ardiesyah, separately iterated similar positions. When I asked why pop Melayu bands, whose compositions enjoyed healthy sales records, were rarely discussed in RSI, Ardiasyah replied: 'None of us consider their music good... [It's] a quality issue', and Siahaan said: 'All those champions of the ring back tone, [Pop Melayu bands] ST 12, Kangen Band, Hijau Daun... In our opinion we are now at the lowest peak of the music industry, quality-wise. And we are not going to give over to them a portion of our magazine, RSI.'

Drawing on Hobart, who argues that Indonesian reality shows on television about criminality serve to scrutinise and humiliate the masses, we might characterise RSI's treatment of pop Melayu as a rite of class. This treatment, that is, can be seen to continue the kinds of ritual maintenance of Melayu-kampungan through print, begun in the early

13 The pop composer and producer Erwin Gutawan (who epitomises a pop music intellectual), and Ridho Hafiedz, the guitarist for Slank, the enormously successful blues-rock band, were quoted in separate articles on an entertainment website lamenting the absence of quality in pop Melayu compositions (http://artis.inilah.com/berita/2009/05/08/105434/erwin-gutawaanggap-pop-melayu-jadul/; http://artis.inilah.com/berita/2009/05/08/105331/ridho-slankmalu-musik-melayu/) 
New Order period when the press and a particular middle sensibility were enjoying consolidation. Certainly, this treatment betrays the defining features of ritual, with its stress on restricted, intellectual knowledge and on maintaining dangerous border zones (Appadurai, 1996), such as the one the kampungan-gedongan dyad sets up, but then can neither be avoided nor denied. Kampungan-gedongan proposes the idea of the unknowing, vulgar masses, but may be thought of as one of the many 'neat [and]...fanciful predeterminations' that entertainment enables (Hobart, 2006: 394). Such predeterminations identify, regulate and survey the masses, but contain the spectre of other possibilities: either that of the masses' illegibility or the threat of commercial expropriation of the kampungan, such as that undertaken by Rhoma Irama himself. Hence the need for ritual maintenance that RSI's treatment of pop Melayu makes apparent.

However forcefully it is promoted in the pages of $R S I$, the fact remains that this pop Indonesia-gedongan realm is one that appears increasingly fragile. The distinction between Western-derived pop Indonesia and Indonesian-derived pop Melayu is more difficult to maintain because there is a convergence of styles and stages and a divergence of opinion within pop Indonesia institutions. As I have mentioned above, pop Melayu acts do not, generally, make use of the suling and gendang that are prominent features of dangdut. They make use of a Western-style drum kit and their compositions most often do not include a suling. Moreover, although pop Melayu bands might not appear in RSI, they do appear side by side with pop Indonesia bands on live and televised stages. They also share producers and managers at recording companies. Finally, and most important, there is increasing uncertainty about what that kampungan signifies, revealing a fragmentation of an Indonesian middleness.

\section{New Developments in Melayu}

In the middle years of this decade, a group of youths from Lampung in Southern Sumatra gathered together and began busking in the time they 
had free from their day jobs (as pushcart traders, construction workers), and later staging more formal performances at music festivals in their home town. By mid-2005, this group had named itself Kangen Band, and recorded a demonstration compact disc of original compositions by its guitarist, Dodhy. Over the course of the rest of the year, and because of orchestrations by band members as well as events beyond their control, Dodhy's compositions could be heard and bought in various strategic public places around Lampung: on the radio, on the bemo, in malls and in the form of compact discs sold by the roadside. By 2006, Kangen Band's popularity manifested itself in similar form on Java (Sujana, 2009).

In 2006, a former print journalist, Sujana, who had recently established an artist management company, Positive Art, discovered Kangen Band and invited its members to pioneer Positive Art's strategy for pop production. When incorporated into the publishing and distribution systems of a major recording label, Kangen Band proved to be commercially successful. But once part of such official systems of musical reproduction, Kangen Band began to assume new form. On signing with Positive Art, Kangen Band became known as a pop Melayu band. The band's commercial success beneath the auspices of major recording label was, then, the event that gave rise to the reemployment of this term, Melayu, to describe an emerging pop genre. Subsequently, in Kangen Band's wake, all of the Jakarta-based, major recording labels have begun to develop 'Melayu' repertoires, and a number of these pop Melayu bands - all of them are boy bands - have also been commercially successful. ${ }^{14}$ As briefly mentioned above, the virtues or otherwise of the emergence on the national stage of these $p o p$ Melayu boy bands were hotly debated in some circles. In particular, the coming to national prominence of Kangen Band, whose appearance on television was much to the chagrin of a considerable number of critics, served as a kind of watershed, revealing profound changes in prevailing

14 An instance of such commercial success, Wali's song 'Baik Baik Sayang', has been activated in ring-back-tone format a record thirteen million times (Solihun, 2010). (In comparison, the record number of officially recorded digital downloads for any one song internationally is 9.8 million: Lady Gaga's 'Poker Face' in 2009.) 
representations of class and prompting people to adopt various positions in new fields of class.

One spectacular example of such changes is provided by Kangen Band's response to criticism. Rather than distancing themselves from the image of provincial vulgarity associated with the term kampungan, the band's publicity machine began to make much of its humble, marginal beginnings. In cinematic and literary form, narratives of the band's rags to riches story appear in chain bookstores and on television. Here is an inspirational story of the wong cilik (little people) battling against the odds. In 2007, for example, after Kangen Band signed with Warner Music, RCTI broadcast a film, titled 'Aku Memang Kampungan' (Proud to be a hick), that recounted the band's rise to fame. The title implies a reclaiming of the term kampungan, a reclaiming that is not without precedent, but which now inhabits a new context.

Such a new context is strongly evoked by the heated debates among pop Indonesia practitioners and intellectuals concerning the quality of Kangen Band's compositions and, more broadly, of all pop Melayu bands' compositions, suggesting that those who inhabit the middle can no longer agree on the cultural position and value of the kampungan. In contrast with the RSI writers, some esteemed pop Indonesia composers have even suggested that many pop Melayu compositions are musically sound. Fariz RM, a pop composer and performer whose heyday in the 1980 s is now being re-celebrated with substantial support from $R S I$, is cited as contributing the following comment to a meeting of experts to discuss the music industry, and published in RSI: 'Don't be sceptical about Kangen Band. Who says Kangen Band is not creative?... Don't forget they have keyed into the spirit of the people, and that is no easy task' (Putranto, 2009: 68). Backstage at the AMI (Akademi Musik Indonesia: Indonesian Music Academy) awards in April 2009, Yovie Widianto (co-winner of Best Recording Producer category and whose band, Yovie and the Nuno, won the AMI award for the best Best of Album) commented: 'Pop Melayu songs are not universally lacking in quality. It's better to perform original compositions than to be a Western wannabe performing plagiarized compositions' (Sulaksono, 2009: 10). 
There are other defences still, such as those that emerge as comments on the YouTube site dedicated to Kangen Band's clip of the song 'Selingkuh' ('Cheating'). Like Fariz RM's comments, some of those who contribute their views betray their willingness to mull over, re-spin and even explode some of the concepts (quality, the metropolis) that pop Melayu's critics reveal as key to their rehabilitation of gedongan's vanguard dimensions.

I am sure all music lovers actually like Kangen Band's songs. It's just that they are pretentious. They are just copying and echoing those who deride Kangen Band as provincial hicks. Look at P Project's song 'Bukan Superstar'. Rhythmically it ispractically the same as Kangen Band's song 'Doy', but because it is sung by P Project, whose members are crazy and cool, everyone thinks it is cool.

wiyanataende

Don't just protest and whinge all the time. This is precisely why Indonesia cannot advance and is still a poor country, because people can only protest all the time, instead of doing something for themselves. Were your ancestors of hundreds of years ago modern, or cool? For those Kangen Band members reading, don't take any notice of those critics. They do not deserve to be given breath by God. Go forward Kangen Band!

\section{VAN3Z20}

To my reading, as is Fariz RM's above-cited comment, the exchanges on YouTube concerning Kangen Band are deeply reflexive. ${ }^{15}$ Much seems up for discussion here: the question of how an interest in the vocalist's physical appearance reflects on consumers, the role of the metropolis in cultural production, the Melayuness or otherwise of

15 The abovecited comments do not reflect the tone of the discussion about the videoclip as a whole. There is considerable disagreement as to the quality of the song and its relationship to kampungan. Notable also is the fact that a number of those to comment on the song clearly delight in exchanging obscenities and in naming the male genitals, highlighting the possibilities this medium offers for spontaneous, interactive, ludic and carnivalesque exchanges and performances; all these qualities are certainly lacking, although not entirely absent, in older text-based media such as the press. 
Kangen Band's music and its implications for the affective qualities of consumption, to name a few. Indeed, the term kampungan is not unpacked here. Nevertheless, the responses to Selingkuh on YouTube do evidence a kind of inquiring, reflexive mode that, it could be argued, disagreements about pop Melayu's quality seem to provoke.

It is highly significant that these inquiries and doubts about the relationship between 'quality', a variant of knowledge, and the kampungan, emerge in a context in which the national public space fills with narratives of upward mobility. One of the memorable ways this optimism forces its ways into domestic space is in the form of multi-level marketing, founded on the very promise of upward mobility. In my own ethnically and socially diverse neighbourhood in Denpasar, growing numbers of my neighbours of various backgrounds spend more and more of their time at multi-level marketing meetings, or refuse to relent in urging other neighbours to either buy their wares or join their meetings.

Another example of the prevalence of narratives of upward mobility is provided by the trilogy of novels based on the novelist Andrea Hirata's childhood in a family in provincial Belitung that had few financial and minimal educational resources but who went on to win a scholarship to the Sorbonne. These novels, which have been made into films to enormous critical and mass acclaim by an esteemed production company, Miles Productions, have proved to be a very powerful explication of the idea that economic hardship allows the possibility for advance. The particular films that exemplify this idea are Laskar Pelangi, made in 2007, and Sang Pemimpi, in 2009.

It is also significant in this context that the greatest profits from the exchange of music are currently generated not by digital downloads of songs, live or televised performances, advertising jingles or album sales, but by ring-back tones. These are thirty-second excerpts of songs that callers hear when they call the number of whoever has purchased a ring-back tone. They are coded and cannot be pirated, and constitute an industry monopolised by large recording labels and telecommunications companies. What is significant about ring-back tones in the context of 
the pervasiveness of narratives of upward mobility, which depict this trajectory as one from the kampung to the metropolis, is that these musical products are, according to telecommunications companies that can track sales by region, most intensively consumed by those living in provincial second-tier and third-tier cities, especially those cities on islands other than Java, therefore most squarely beyond the fringes of Jakarta (Solihun, 2010: 36).

\section{Conclusion}

This article has argued that the matter of RSI's attempt to address the pria dewasa can be understood in a context in which a myth of class evolved in tandem with a new chapter in print capitalism on the advent of the New Order. As such, it has drawn heavily on those writings that stress the ways in which Indonesian myths of class and the press intersect. Indeed, the idea emerges in a number of recent studies (Ferry, 2003; Leichty, 2003; Mazzarella, 2003; Wang, 2008) that other countries of the Asian region feature a middle space, between a looming, imposing or modernising force (such as 'the state', 'the global' or 'capital') and the (unmodern) masses, and this space is inhabited by those empowered to manipulate media in (the name of) the masses' best interests. However, departing from scholarly discussions of the role of print in the imagining of national communities, newer studies explore how this middle space has evolved in globalised media environments, which have important post-industrial features for the importance advertising images play in them.

These studies of middle classness in image economies of the Asian region offer new tools for reading contemporary developments in Indonesian pop and class; tools that allow other interpretations of the slew of publications that place an Indonesian middle class in the context of a structural modernisation, and of those that stress a crucial link between myths of class and the press. In his book on India, Mazzarella explores the cultural implications of that country being subjected to a global trend in media deregulation. Such deregulation, 
he argues, allowed a middle class to occupy a hinge position, creating local content in the context of global media firms. In this way, such hinge occupants contribute to aspirational consumerism: the idea of the nation as a collection of sovereign consumers, all aspiring to a uniform middleness, generously imaged. Leichty (2003: 37) argues that Nepali consumerism is similarly hegemonic, and contends that ' $[\mathrm{y}]$ outh act as the vanguard of an emerging middle class consumerculture. Constituting youth as consumers is the same cultural project as constituting middle class subjects. Producing youth is producing the middle class.'

In a separate article (Baulch, 2007b) I have argued that in mediaderegulated Indonesia too, youth culture, specifically pop music culture, newly imaged on new, advertising-funded television with national reach, has served as a convenient default position for public constructions of middleness. By appearing to pertain primarily to youth, not class, pop music obscures the ideological connotations of such constructions, hence helps naturalise them. I have also argued that consumerism must adopt modes of address that assume the homogeneous middleness of the Indonesian citizenry, newly defined as a collection of sovereign consumers. Notably, such modes of address gloss over kampungangedongan distinctions.

But as it turns out, Indonesian aspirational consumerism's moment was only fleeting, and the advent of pop Melayu signals something new. As we have seen above, pop Melayu is a metropolitan construction, but no longer does a Jakarta-based eye survey the provinces and recreate them in its own image. Pop Melayu retrieves, to an extent, the kampungangedongan dyad. But it does so in a context in which the kampungan, that marker of Otherness that has been so important to the evocation of an Indonesian middleness, is increasingly unstable. Moreover, it is being incorporated into narratives of upward mobility, such as one finds in the way in which pop Melayu has been spun and pitched as a genre to consumers. ${ }^{16}$ No longer just the waste, the un-modern, the vulgar

16 This development in itself is by no means unique to Indonesia; in the idea that third-tier cities represent lucrative markets now emerge in the imaginings of advertisers in other countries at comparable stages of market development (Wang, 2008), and in this sense contemporary pop Melayu is heavily laden with globally-circulating marketing discourses. 
(although these significations endure), kampungan can now also signify the possibility of bettering oneself.

\section{References}

Appadurai, Arjun. (1996). Modernity at large: the cultural dimensions of globalization . Minneapolis, University of Minnesota Press.

Aristi, Yarra. 2008. 'Here she comes now'. Rolling Stone 40: 54-63.

Barendregt , Bart. (2002). 'The sound of "Longing for Home": Redefining a sense of community through Minang popular music'. Bijdragen tot der Taal-, Land- en Volkenkunde. 158 (3): 411-50.

Baulch, Emma. (2007a). Making scenes: punk, reggae and death metal in 1990s Bali. Durham: Duke University Press.

. (2007b). 'Cosmopatriotism in Indonesian pop music imagings'. In (eds) Edwin Jurriens and Jeroen de Kloet. Cosmopatriots: on distant belongings and close encounters. Amsterdam: Rodopi, 2007). pp. 177-204.

Browne, Susan. (2000). The gender implications of dangdut kampungan: Indonesian 'low class' popular music. Monash University Insititute for Asian Studies Working Paper 109. Clayton: Monash University Centre of Southeast Asian Studies.

Coutas, Penelope. (2008). 'Fame, fortune, fantasi: Indonesian Idol and the New Celebrity'. In (ed.) Ariel Heryanto. Popular culture in Indonesia: fluid identities in post-authoritarian politics. London and New York: Routledge. pp. $111-129$.

Crouch, Harold. (1986). 'The missing bourgeoisie: approaches to Indonesia's New Order'. In (eds) David Chandler and Merle Rickleffs. Nineteenth and twentieth century Indonesia: essays in honour of Professor J.D. Legge. Clayton: Centre of Southeast Asian Studies, Monash University.

David, Bettina. (2003). 'The erotics of loss: some remarks on the pleasure of dancing to sad dangdut songs'. Paper presented at the workshop 'Pop Music in Southeast Asia', Leiden, The Netherlands, 8-12 December.

Dhakidae, Daniel. (2003). Cendekiawan dan kekuasaan dalam negara Order Baru. Jakarta: Penerbit PT Gramedia Pustaka Utama.

Dick, Howard. 'The rise of the middle class and the changing concept of equity'. In (eds) Richard Tanter and Kenneth Young. The politics of middle-class Indonesia. Glen Waverley: AristocPress. pp. 71-92.

Farid, Hilmar. (2005). 'The class question in the Indonesian social sciences'. In (eds) Vedi R Hadiz and Daniel Dhakidae. Social science and power in Indonesia. Jakarta and Singapore: Equinox and Institute of Southeast Asian Studies. pp. 167-96. Ferry, Megan. (2003). 'Advertising, consumerism and nostalgia for the New Woman in contemporary China', Continuum: Journal of media and cultural studies, 17 (3): 277-290. 
Frederick, William. (1982). 'Rhoman Irama and the dangdut style: aspects of contemporary Indonesian popular culture'. Indonesia, 32: 103-30.

Gjelstad, Lars. (2003). 'The world of sparkling lights: popular music and teenage culture in Solo, Central Java'. Paper presented at the workshop 'Pop Music in Southeast Asia', Leiden, The Netherlands, 8-12 December.

Hadiz, Vedi R and Daniel Dhakidae. (2005). 'Introduction'. In (eds) Vedi R Hadiz and Daniel Dhakidae. Social science and power in Indonesia. Jakarta and Singapore: Equinox and Institute of Southeast Asian Studies. pp. 21-22.

Hatley, Barbara. (2008). Javanese performances on an Indonesian stage: contesting culture, embracing change. Singapore: NUS Press.

Heins, Ernst. (1975). 'Keroncong and Tanjidor: two cases of urban folk music in Jakarta'. Asian Music, 7 (1): 20-32. (Southeast Asia issue)

Heryanto, Ariel. (2003). 'Public intellectuals, media and democratization'. In (eds) A Heryanto and SK Mandal. Challenging authoritarianism in Southeast Asia; comparing Indonesia and Malaysia. London: RoutledgeCurzon. pp. 24-59.

-------. (2008). 'Pop culture and competing identities'. In (ed.) Ariel Heryanto. Pop culture in Indonesia: fluid identities in post-authoritarian politics. London: Routledge.

-------. (2010). 'Entertainment, domestication and dispersal: street politics as popular culture'. In (eds) Edward Aspinall and Marcus Mietzner. Problems of democratisation in Indonesia: elections, institutions and society. Singapore: ISEAS Publishing. pp. 181-198.

Heryanto, Ariel and Stanley Yoseph Adi. (2002). 'Industrialized media in democratizing Indonesia'. In (ed.) Russell HK Heng. Media fortunes, changing times: ASEAN states in transition. Singapore: Institute of Southeast Asian Studies.

Hill, David T. (1994). The press in New Order Indonesia. Nedlands: University of Western Australia Press.

Hill, David and Sen, Krishna. (2005). The Internet in Indonesia's new democracy. London and New York: Routledge.

Hobart, Mark. (2006). 'Entertaining illusions: how Indonesian élites imagine reality TV affects the masses'. Asian journal of communication, 16(4): 393-410.

Ibrahim, Idi Subandy (ed.). (1997). Lifestyle ecstasy: kebudayaan pop dalam masyarakat komoditas. Yogyakarta: Jalasutra.

Jawa Pos. (2009). 'Jalan sesama, acara pendidikan yang tak kejar keuntungan: tak peduli rating, selektif terima iklan'. Jawa Pos, Desember 6, p. 9.

Jaya, Hadi. (1999). 'Dari Redaksi'. In (ed.) Hadi Jaya. Kelas menengah bukan ratu adil. Yogyakarta: Tiara Wacana. pp. vii-xxvi.

Jaya, Hadi (ed.). (1999). Kelas menengah bukan ratu adil. Yogyakarta: Tiara Wacana.

Keane, Webb. (2009). 'Freedom and blasphemy: on Indonesia press bans and Danish cartoons'. Public culture, 21(1): 47-76.

Khalik, Abdul. (2005). 'Adiguna, spoilt brat of famed tycoon'. Jakarta Post, 14 January. 
Lev, Dan. (1990). 'Intermediate classes and change in Indonesia: some initial reflections'. In (eds) Richard Tanter and Kenneth Young. The politics of middleclass Indonesia. Glen Waverley: AristocPress. pp. 25-43.

Liddle, R. William. (1990). 'The Middle Class and New Order Legitimacy'. In (eds) Richard Tanter and Kenneth Young. The politics of middle-class Indonesia. Glen Waverley: AristocPress. pp. 49-52.

Liechty, Mark. (2003). Suitably modern: making middle-class culture in a new consumer society. Princeton: Princeton University Press.

Luvaas, Brent. (2009a). 'Dislocating sounds: the deterritorialization of Indonesian indie pop'. Cultural anthropology, 24(2): 246-279.

-------. (2009b). 'Review essay: modern cacophanies'. Indonesia 88, October: 17583.

Mazzarella, William. (2003). Shoveling smoke: advertising and globalization in contemporary India. Durham and London: Duke University Press.

McLeod, Kembrew. (2001). 'A critique of rock criticism in North America'. Popular Music, 20(1): 47-60.

Mulyadi, Muhammad. (2009). Industri musik Indonesia: suatu sejarah. Bekasi: Koperasi Ilmu Pengetahuan Sosial.

Murray, Alison. (1991). 'Kampung culture and radical chic in Jakarta'. Review of Indonesian and Malayan affairs, 25(1): 1-16.

Pandey, Gyanendra. (2009). 'Can there be a subaltern middle class? Notes on African American and Dalit history'. Public culture, 21(2): 321-342.

Pioquinto, Ceres. (1995). 'Dangdut at Sekaten: Female representations in live performance'. Review of Indonesian and Malayan affairs, 29(1-2): 59-89.

Piper, Suzan and Jabo, Sawung. (1987). 'Musik Indonesia, dari 1950-an hingga 1980an', Prisma, (16)5: 8-19.

Putranto, Wendi. (2008a). 'Ketika Glenn Resah'. Rolling Stone, 40: 100-103.

-------. (2008b). 'Six string sultans: new blood'. Rolling Stone, 39: 40. - (2009). 'Inilah musik Indonesia hari ini'. Rolling Stone, 47: 64-71.

Republika. (2008. Republika Sabtu, 01 November 2008. 'Masih eranya pop Melayu'. Downloaded from http://mellowtone.multiply.com/tag/st\%2012 on 19 August, 2009.

Robison, Richard. (1986). Indonesia: the rise of capital. Sydney: Allen and Unwin. . (1990). 'The Problems of Analysing the Middle Class as a Political Force in Indonesia' In (eds) Richard Tanter and Kenneth Young. The politics of middleclass Indonesia. Glen Waverley: AristocPress. pp. 137-147.

-------. (1996). 'The middle class and the bourgeoisie in Indonesia'. In (eds) Richard Robison and David SG Goodman. The new rich in Asia: mobile phones, McDonalds and middle class revolution. London: Routledge. pp. 70-104.

Romano, Angela. (2003). Politics and the press in Indonesia: understanding an evolving political culture. London and New York: Routledge Curzon. 
Sen, Krishna and Hill, David T. (2000). Media, culture and politics in Indonesia. Melbourne: Oxford University Press.

Setiyono, Budi. (2001). 'Ngak ngik ngok'. Pantau, (2)18: 38-47.

Solihun, Soleh. (2004). 'Perjalanan majalah musik di Indonesia'. Thesis for communications degree. Bandung: Universitas Padjadjaran, Fakultas Ilmu Komunikasi, Jurusan Ilmu Jurnalistik.

- (2009). 'Gemini sang primadona'. Rolling Stone, 54: 44-48.

. (2010). 'Nada sambung bawa untung'. Rolling Stone, 59: 30-36.

Sometimes, Alicia. (2006). 'Women and rock: is rock'n'roll a male preserve?'. Meanjin, 65(3): 31-94.

Sopiann, Agus. (2001). 'Putus Dirundung Malang'. Pantau, (2)16. . (2002). 'Lima Raksasa Internasional di Indonesia'. Pantau, (3)25: 40-47.

Steele, Janet. (2005). Wars within: the story of Tempo, an independent magazine in Soeharto's Indonesia. Jakarta and Singapore: Equinox and Institute of Southeast Asian Studies.

Sulaksono, Sugeng. (2009). 'Rancu antara Melayu dan pop'. Jawa Pos, 26 April: 10.

Tanter, Richard. and Young, Kenneth. (1990). 'Editors' introduction'. In (eds) Richard

Tanter and Kenneth Young. The politics of middle-class Indonesia. Glen Waverley: AristocPress. pp. 7-21.

Wallach, Jeremy. (2002). 'Exploring class, nation and xenocentrism in Indonesian cassette outlets'. Indonesia, 74: 79-102.

. (2008). Modern noise, fluid genres: popular music in Indonesia, 1997-2001. Wisconsin: University of Wisconsin Press.

Wang, Jing. (2008). Brand new China: advertising, media and commercial culture. Cambridge and London: Harvard University Press.

Weintraub, Andrew N. (2006). 'Dangdut soul: who are 'the People' in Indonesian popular music?'. Asian journal of communication, 16(4): 411-431.

Yampolsky, Philip. (1989). 'Hati yang Luka: an Indonesian hit'. Indonesia, 47: 1-17. Zulkarnain, Happy Bone, Faisal Siagian and Laode Ida. (1993). 'Kelas menengah digugat: catatan editor'. In (eds) Happy Bone Zulkarnain, Faisal Siagian and Laode Ida. Kelas mengenah digugat. Jakarta: Fikahati Aneksa. pp. 9-26.

\section{Interviews}

Adib Hidayat, Managing Editor, RSI, 6 October 2009

Hasief Ardiasyah, Associate Editor, RSI, 8 October 2009

Andy F Noya, President Director, RSI, 9 October 2009

Monika Soebari, Vice-President, RSI, 9 October 2009

Ricky Siahaan, Associate Editor, RSI, 8 October 2009

Soleh Solihun, Editorial Staff, RSI, 6 October 2009

Wendi Putranto, Editorial Staff, RSI, 26 June 2009 
ARTICLES

Wening Gitomartoyo, Editorial Staff, RSI, 7 October 2009

\section{Websites}

http://artis.inilah.com/berita/2009/05/08/105434/erwin-gutawa-anggap-pop-melayujadul/

http://artis.inilah.com/berita/2009/05/08/105331/ridho-slank-malu-musik-melayu/

\section{Films}

Laskar Pelangi, Miles Productions, 2007

Sang Pemimpi, Miles Productions, 2009 